\title{
The Arctic of the Future: Retrospective And Perspective of Research and Development
}

\author{
Rocheva Olga \\ Kazan Cooperative Institute (branch) of the Russian \\ University of the Cooperation \\ Kazan, Russia \\ rochevaolga@mail.ru \\ Zaripova Rimma \\ Kazan State Power Engineering University \\ Kazan, Russia \\ zarrimma@mail.ru
}

\author{
Khadiullina luliia \\ Kazan Innovative University named after V.G. Timiryasov \\ (IEML) \\ Kazan, Russia \\ yhadiullina@ieml.ru \\ Hamatgaleeva Gulia \\ Kazan Cooperative Institute (branch) of the Russian \\ University of the Cooperation \\ Kazan, Russia \\ sting74@mail.ru
}

\author{
Kosulin Valery \\ Kazan State Power Engineering University \\ Kazan, Russia \\ valerakosulin@rambler.ru
}

\begin{abstract}
The efficiency of foreign investments, which is directly related to the specifics of intra-industry specialization and economic opportunities of national States, is considered. In natural and climatic terms, the Arctic is a unique region of The globe. Glaciers and permafrost are common in this area. The Arctic zone is characterized by such climatic signs as excessive moisture, cold summers, long winters. The Arctic zone is the shortest route between such important points of The globe as North America, Southeast Asia and Europe.

The approach based on the development of fuel and energy resources in the Arctic region of Russia, for improving the effectiveness of state energy and total ozdorovlenie energy and transport system.
\end{abstract}

Keywords: economy, investments, Arctic, energy resources

\section{INTRODUCTION}

The specific geographical position of the Arctic determines its special status, which currently requires study and analysis. The Arctic is a vast territory on the physical map of the Earth, which is characterized by a unique climate and nature.

In this regard, the Arctic is currently a region that has pronounced characteristics in the environmental, economic, political, strategic and geopolitical sphere, which determine the difference of this territory from all other regions of The globe. The Arctic also plays a special role in the system of international relations and transport communications.
The effectiveness of foreign investments is directly related to the specifics of intraindustrial specialization and economic opportunities of national States [5].

For example, the United States focuses on exploration, improvement of scientific research and development, development of project management. Canada in its Arctic zone effectively regulates the social aspects of oil production, uses the environmental regime to protect the interests of the national oil sector. Norway actively attracts private capital, the most effective among all Arctic countries carries out research and implementation of modern technologies.

The relevance of this study is associated with a whole range of new phenomena in the development of the transport system of our country and the world as a whole. The States that have interests in the Arctic zone, in modern conditions, carry out complex scientific developments in this territory and actively interact to achieve joint tasks on the basis of mutually beneficial cooperation.

The Arctic is the Northern polar region of The globe, which includes the adjacent territories of the Eurasian and North American continents, the Arctic ocean and the Pacific and Atlantic oceans.

The word "Arctic" has a Greek origin and translated into Russian means "Northern". In General, at the present stage can be considered an established understanding of the Arctic 
2) accounting for inter-corporate and inter-national competition;

3) the need to overcome the complex of climatic and technical and technological features that impede the favorable development of the Arctic zone;

4) the possibility of improving the efficiency of regulation of organizational and legal aspects of access to mineral resources and fuel and energy resources of the North;

5) the possibility of implementing an integrated approach to solving environmental and conservation problems in relation to the North.

Among the bilateral and multilateral relations of the Russian Federation concerning the Arctic zone and its resources, a special place now belongs to relations with China.

The position of this state on the development of the Arctic region should be objectively taken into account in modern conditions, since the obvious fact is the interest of the fuel and energy complex of China in expanding penetration into the Arctic. Therefore, China can be considered one of the leading partners of Russia in the development of fuel and energy resources of the Arctic zone. General, the settlements located in the Arctic zone are small and often have a specialized character. Mass settlement of the Arctic by people is hampered by the duration and severity of winter, excessive moisture, almost complete absence of conditions for agricultural work, limited flora and fauna.

The Arctic zone is the shortest route between such important points of The globe as North America, Southeast Asia and Europe. At the state level, China is aware that climate change has a serious impact on the environment, the state of agricultural production, commercial Maritime navigation, as well as the overall nature of the socio-economic development of the country. In 2017, the Arctic region was included by China in the three blue sea corridors under the Belt and road initiative [6

The Chinese company is involved in cargo delivery operations in the Arctic. The company of specialized carriers (COSCOL), which operates under the auspices of China Ocean Shipping Company (COSCO), the first flight on the Northern sea route was sent in the summer of 2013 - an iceclass cargo ship owned by COSCOL. According to official estimates, since the first voyage, COSCOL has ten ships making fourteen voyages through the Arctic.

The savings appear to be significant: fourteen trips in total saved a distance of 67,390 nautical miles, reducing travel time by 220 days, fuel by 6,948 tons, and costing US $\$ 9.36$ million. To confirm the consistent viability of the Northern Sea route, COSCOL has used vessels sailing through the NSR every year since 2015 . The company estimates that more than ten ships continued the mission in 2018.

Russia is currently participating in the Arctic Council on a range of energy and transport issues. The position of the Russian Federation in relations with the Arctic States is due to the influence of the following factors:

1) the need for the development of transport infrastructure as one of the most promising sectors of the modern economic system;

\section{METHODS}

Russia has a significant advantage over other States in terms of the availability of energy resources in the Arctic zone. In the global volume of Arctic fuel and energy resources, Russia owns more than $70 \%$ of oil and more than $90 \%$ of gas. However, only about $3 \%$ of this array of fuel and energy resources of Russia is currently used. The reason for the insufficient development of the Arctic resource potential is the insufficient development of transport infrastructure, the lack of special deep-water and ice equipment, etc.

China is actively involved in joint investment programs for the production of oil and gas in the Arctic and other natural resources, the construction of transport and energy infrastructure, the development of biological resources of the Arctic seas, the development of Arctic tourism. However, China is now ready to interest the Arctic and non-Arctic partner countries not only in the volume of trade turnover along the Arctic blue economic corridor and investments, but also in many technological and innovative solutions for use in the Arctic [6,9].

Due to the presence of mineral deposits in the Arctic zone, the task of developing transport infrastructure in this region was actualized. The solution of this problem was devoted to the development of research of Soviet industry and science, since the 30-40s of the XX century.

Due to the need to develop mineral and natural resources in the Arctic, it was necessary to form a transport system, vital for navigation. The task of creating an icebreaker fleet of increased capacity came to the fore.

Currently, the processes taking place in the Arctic region require significant efforts by the state to increase the presence of the nuclear icebreaker fleet in the Arctic. Characteristic 
Russia expects an increase in Chinese investment in projects for the extraction and processing of natural resources and the development of transport and logistics infrastructure, an increase in oil exports, "Belt and road".

However, the real implementation of the concept of the Arctic blue economic corridor as a viable alternative to traditional sea routes is impossible without Russia's deep comprehensive efforts to increase the investment attractiveness of the Russian Arctic and the creation in this region of a powerful and modern transport and logistics infrastructure with broad attraction of foreign capital.

Currently, there are 10 investment projects for the development of mineral resources associated with the use of the marine transportation scheme, the routes of which are located in the waters of the North sea route- 5 are associated with the development of hydrocarbon raw materials, 5 - ores and coal.

The main projects forming the cargo base are located in the areas of the Ob Bay and the Yenisei Bay of the Kara sea. It is expected that the main volume of cargo traffic will be associated with the transportation of energy resources-LNG, oil and coal. Smaller in volume, but significant from strategic positions, the volume of transportation will be associated with the export of concentrates of non-ferrous and precious metals (Dudinka, Pevek).

On the coast of the East Siberian sea is developing a gold Deposit may with the seasonal export of concentrate in the amount of about 0.1 million $t$. the Beginning of the development of Peschanka Deposit (Baimka area) provided by the terms of use of mineral resources no later than October 2026; according to the company, the export of copper and molybdenum concentrate are estimated at 680 thousand tons per year.

Possible year-round joint export of raw materials projects Gerbil and May through the port of Pevek.

It is expected that the new region of oil production will be the area of the Khatang Bay of the Laptev sea, where in April 2017 search and evaluation drilling by Rosneft and LUKOIL was started.

The area is characterized by proven oil and gas potential, the company obtained signs of the presence of oil in the drilling process, the identification of deposits is carried out. In accordance with the terms of subsoil use, LUKOIL (license KRR15948NR) has a binding condition to enter the open field into development no later than 2023.

In connection with the discovery in the Arctic of giant deposits of minerals, primarily hydrocarbons, and the observed dramatic warming of the climate in the Arctic, the interest in this region has increased dramatically in many countries, not only adjacent to this area.

Russia was able to prove that the Mendeleev and Lomonosov ridges are an extension of its continental shelf and, accordingly, can increase its Arctic territory by 1.2 million square kilometers.
For both China and Russia, the implementation of the Arctic blue economic corridor initiative brings significant economic and geopolitical benefits. Among other things, 
- geophysical development.

The presence of mineral deposits on the shelf of the Arctic ocean causes increased interest of the world community to this region. At the same time, not only the traditional Arctic States, but other countries are beginning to show interest in the development of minerals concentrated in the Arctic and are taking legal steps to penetrate into this geographical zone.

Currently, the world community is interested in the development of fuel and energy, forest and mineral resources of the Arctic region. Hydrocarbon raw materials occupy a special place in the total array of natural resources of the Arctic.

A necessary condition for Russia's active activity in the Arctic is the further development of its icebreaking fleet, primarily nuclear.

The Northern sea route is a key infrastructure object of the Arctic region. Without further development of its infrastructure, the implementation of a number of important projects for the Russian Federation is threatened.

Foreign countries are very interested in cooperation in the development and production of minerals, primarily hydrocarbons. In this regard, international cooperation is increasingly developing for the development of navigation in the Arctic region.

In connection with the opportunity to radically change the status of the Northern sea route, which opened after the weakening and subsequent collapse of the USSR, European countries began to actively demand changes in the status of navigation in the Arctic zone.

Proposals to turn the Northern sea route into a commercial transit route of an international character have become increasingly pronounced. At the present stage, a number of countries in Europe and the world do not leave initiatives to change the conditions of navigation in the Arctic zone and the status of the Northern sea route.

The solution of the problem of this level and scale involves significant changes in the current Russian customs, tax, currency, civil and immigration legislation. In such a situation, the risk for China is the degree of readiness of the Russian side to make real efforts to modernize its legislation and create conditions favorable for large-scale attraction of Chinese investments.

At the present stage it seems expedient to direct foreign investments primarily in the following areas: scientific cooperation, development of new approaches to the development of the Arctic through the use of modern national achievements and developments, extraction, processing and transportation of Northern fuel and energy resources, the development of industry education.

\section{CONCLUSION}

The sphere of state regulation, in turn, should include the following areas of activity:

- geological work,

- exploration activities,
This approach seems to be quite justified, as it is based on military-strategic and geopolitical principles.

A full-fledged competitive award of contracts for participation in the development of fuel and energy resources of the Arctic, which meets international requirements, should become the basis for attracting foreign investment. Through the use of a competitive Contracting system, it is possible to use competitive mechanisms to achieve high profitability.

The development of fuel and energy resources of the Arctic region of Russia requires a wide and full-scale use of the best practices of foreign countries. Such an approach should become the basis for a significant increase in the efficiency of providing the state with energy resources and the overall improvement of the energy and transport system.

Among the bilateral and multilateral relations of the Russian Federation regarding the Arctic zone and its resources, relations with China currently hold a special place. The position of this state on the development of the Arctic region should be objectively taken into account in modern conditions, since the obvious fact is the interest of the Chinese fuel and energy complex in expanding its penetration into the Arctic. China is actively involved in the global discussion on the prospects for the development of the Northern sea route and international cooperation in the Arctic. Thus, since China's accession as an observer to the Arctic Council, it can be concluded that China is moving from exclusively research activities to active participation in the development and development of the Arctic and the realization of its economic and geopolitical interests in the region. Therefore, China can be considered one of the leading partners of Russia in the development of fuel and energy resources of the Arctic zone.

At the same time, taking into account the interests of other participants in the discussion on Arctic issues, the Russian Federation is aware of the fact that it currently possesses unique fuel and energy resources in the North and has a priority position in terms of access to the Arctic ocean. Russia's energy strategy, developed until 2020, assumes an increase in oil production in the Arctic region of 95 million tons and 320 billion cubic meters of gas.

Russia has a significant advantage over other States in terms of the availability of energy resources in the Arctic zone. In the global volume of Arctic fuel and energy resources, Russia owns more than $70 \%$ of oil and more than $90 \%$ of gas. However, only about $3 \%$ of this array of fuel and energy resources in Russia is currently used. The reason for the insufficient development of the Arctic resource potential is the insufficient development of transport infrastructure, the lack of special deep-water and ice equipment, etc.

\section{REFERENCES}

[1] I.T. Gaising, R.I. Gaising, R.S. Sharipov, D.M. Guseynov, "Pedagogical technologies in ecology-geographical education of school students," Scientific developments: Eurasian region: materials of the International scientific conference of theoretical and applied developments, 2019, pp. 110-113. 
[13] A.V. Chupaev, R.S. Zaripova, R.R. Galyamov, A.Y. Sharifullina, "The use of industrial wireless networks based on standard ISA-100.11a and protocol WirelessHART in process control," E3S Web Conf., vol. 124, 2019, p. 03013.

[14] R.S. Zaripova, E.A. Saltanaeva, N.G. Bikeeva, E.V. Priimak, "Development of quality monitoring devices for industrial water in heat supply systems," IOP Conference Series: Earth and Environmental Science, vol. 288, 2019, pp. 012129.

[15] L.V. Plotnikova, R.R. Giniyatov, S.Y. Sitnikov, M.A. Fedorov, R.S. Zaripova, "Perfection of the methodology for developing industrial secondary energy generation systems," IOP Conference Series: Earth and Environmental Science, vol. 288, 2019, pp. 012069.

[16] L.V. Plotnikova, G.I. Efremov, S.Y. Sitnikov, I.I. Chilikova, "Energyresource-saving system «distillation unit - heat pump» for industrial separation of substances," 2018 International Multi-Conference on Industrial Engineering and Modern Technologies (FarEastCon), 2019, DOI: 10.1109/FarEastCon.2018.8602494.

[17] L.V. Plotnikova, L.A. Kashipova, "Development of software for analysis of the structure of industrial heat and power systems," Source of the Document 2016 2nd International Conference on Industrial Engineering, Applications and Manufacturing, ICIEAM 2016 - Proceedings 7911675.

[8] A.G. Vasiljev, "Evolutionary ecology in the 21st century," Russian journal of ecology, 2019, pp. 102-114, DOI: 10.1134/S1067413619020103

[9] O.A. Rocheva, Bulletin of Kazan technological University, vol. 15(10), 2012, pp. 322-328.

[10] O.A. Rocheva, "The place of innovation infrastructure in technology transfer in the Russian Federation," Vestinik Kazan Technological University, vol. 10, 2012.

[11] L.V. Plotnikova, I.I. Chilikova, "Systematic approach to the assessment of energy complex efficiency for thermal energy production with heat power saving transformer turning," International Journal of Pharmacy and Technology vol. 8(4), 2016, pp. 26727-37

[12] L.V. Plotnikova, L.A. Kashipova, "Modeling of heat and power system optimal structure using software," Journal of Engineering and Applied Sciences, vol 11(14), 2016, pp. 3028-34.

[18] L.V. Plotnikova, I.I. Chilikova (Philonova), S.Y. Sitnikov, G.I. Efremov, "Systematic approach to the assessment of energy complex efficiency for thermal energy production with heat power saving transformer turning," International Journal of Pharmacy and Technology, vol. 8(4), 2016, pp. 26727-26737.

[19] L.V. Plotnikova, L.A. Kashipova, R.A. Ishmuratov, "Modeling of heat and power system optimal structure using software," Journal of Engineering and Applied Sciences, vol. 11(14), pp. 3028-3034

[20] A.D. Hayaleeva, R.I. Gaysin, I.T. Gaixing, "Development of geological and geographical education at the Kazan pedagogical university," Modern problems of science and education, vol. 2, 2019, pp. 32. 